\title{
ANALISIS MINAT BELAJAR SISWA SMA PADA MATERI SISTEM PERSAMAAN LINEAR TIGA VARIABEL
}

\author{
Devia Haedi Pyarsha ${ }^{1}$, Dadang Rahman Munandar ${ }^{2}$ \\ . ${ }^{1,2}$ Program Studi Pendidikan Matematika, Universitas Singaperbangsa Karawang \\ Email: pyarshahaedi18@gmail.com
}

\begin{abstract}
Abstrak:
Penelitian ini bertujuan untuk menganalisis minat siswa pada pembelajaran matematika khususnya pada materi sistem persamaan linear tiga variabel. Subjek penelitian ini ialah siswa/siswi SMA Kelas X di salah satu SMA Negeri di Karawang. Instrumen penelitian yang digunakan yakni angket minat belajar siswa dengan jumlah pernyataan sebanyak 18 butir item yang memuat pernyataan positif dan pernyataan negatif serta memuat 4 (empat) indikator minat belajar, diantaranya : 1) Perasaan senang/suka, 2) Perhatian, 3) Ketertarikan, dan 4) Keterlibatan siswa serta hasil observasi selama proses pembelajaran matematika khususnya pada materi SPLTV. Hasil yang diperoleh dalam penelitian ini menunjukkan bahwa masing-masing indikator dari minat belajar siswa termasuk ke dalam kategori cukup dengan persentase lebih dari 50\%.
\end{abstract}

Kata Kunci: Minat Belajar, Matematika, SPLTV

\begin{abstract}
:
This study aims to analyze students interest in learning mathematics, especially in the material of three variable linear equation systems. The subjects of this study were $\mathrm{X}$ class high school students in one of the public high schools in Karawang. The research instrument used was students interest with 18 item statements containing positive statements and negative statements and containing 4 (four) indicators of interest in learning, including : 1) Feelings of pleasure/like, 2) Attention, 3) Interest, and 4) Student involvement as well as the results of observations during the mathematics learning process, especially in the SPLTV material. The results obtained in this study indicate that each indicator of students interest in learning falls into the sufficient category with a proportion of more than $50 \%$.
\end{abstract}

Keywords: Interest to Learn, Mathematics, SPLTV

\section{Pendahuluan}

Matematika merupakan suatu mata pelajaran yang terdapat disetiap jenjang sekolah pendidikan formal, mulai dari jenjang Sekolah Dasar sampai jenjang Sekolah Menengah Atas (Rahmah, 2013). Penting nya mempelajari matematika sejak dini karena ilmu matematika sangat erat kaitannya dengan permasalahan dikehidupan sehari-hari. Selain itu, matematika juga biasanya digunakan sebagai mata pelajaran untuk mengukur kemampuan atau kecerdasaran. Hal ini terbukti dari berbagai tes yang dilakukan, baik itu untuk ujian kelulusan seperti Ujian Nasional (UN), ujian masuk perguruan tinggi bahkan sampai ujian tes untuk bekerja pun matematika tetap digunakan.

Matematika merupakan mata pelajaran dasar, pentingnya mempelajari matematika adalah karena didalam kehidupan sehari-hari mau atau tidak mau kita pasti akan bertemu pengaplikasian dari matematika (Siagian, 2015). Bukan hanya itu saja, ilmu matematika juga dapat mengembangkan kesadaran manusia mengenai nilai-nilai esensial yang terdapat didalamnya. Selain itu menurut UndangUndang No. 23 Tahun 2003 tentang Sistem Pendidikan Nasional Pasal 37 Ayat 1 menyatakan bahwa "Kurikulum pendidikan dasar dan menengah wajib memuat matematika". Tak heran jika matematika ini menjadi salah satu mata pelajaran yang selalu dipelajari disekolah manapun serta penting untuk dikuasai oleh semua siswasiswi disetiap jenjang pendidikan.

Di Indonesia, sebagian besar siswasiswi sudah menganggap matematika merupakan mata pelajaran yang sulit, 
sehingga sebagian besar menghindari mata pelajaran tersebut. Salah satu materi yang dianggap sulit adalah persamaan linear tiga variabel atau biasa disingkat dengan SPLTV. SPLTV sendiri merupakan sub materi matematika yang cara penyelesaian nya mengedepankan ketelitian dalam menghitung. Hal ini bukan berarti materi matematika lain tidak membutuhkan ketelitian, melainkan dalam SPLTV ini proses dalam menyelesaikan permasalahan sangat panjang dan terdapat berbagai cara sehingga ketelitian serta fokus siswa sangat dibutuhkan.

Rendahnya minat siswa dalam belajar khususnya dalam pelajaran matematika juga dibuktikan dari hasil observasi yang dilakukan oleh (Marti'in, 2019) mengatakan bahwa berdasarkan hasil observasinya masih terdapat permasalahan mengenai minat belajar siswa. Masalah yang paling penting adalah rata-rata dari peserta didik sering berbicara sendiri ketika proses pembelajaran berlangsung. Tidak hanya itu, terkadang peserta didik juga sibuk bermain handphone disaat jam pelajaran berlangsung, tidak bersemangat dikelas sehingga selalu meminta izin untuk keluar kelas dan malas untuk bertanya.

Padahal minat merupakan salah satu faktor yang dapat menentukkan keberhasilan seseorang dalam melakukan suatu kegiatan, mulai dari belajar sampai dengan bidang pekerjaan. Menurut (Pangestu, Samparadja, \& Tiya, 2015) Peran minat dalam belajar memiliki pengaruh yang cukup besar. Karena, siswa tidak akan belajar dengan baik jika tidak memiliki daya tarik dalam dirinya. Sebaliknya, jika siswa memiliki suatu minat terhadap suatu pelajaran yang sedang dipelajari, maka siswa akan lebih menikmati dan memperhatikan pelajaran yang sedang dipelajari dan dampak nya siswa akan lebih mudah mengerti dari apa yang telah disampaikan oleh guru karena dengan adanya minat siswa akan senantiasa belajar tanpa adanya suatu paksaan.

Sejalan dengan hal tersebut, menurut apa yang disampaikan oleh Hadjana 1994 minat merupakan suatu keinginan dari dalam diri individu berdasarkan kebutuhan tertentu yang dapat dirasakan maupun tidak dirasakan. Menurut Djaali 2007 juga mengungkapkan hal yang serupa yakni minat adalah suatu perasaan senang atau rasa tertarik yang lebih terhadap suatu aktivitas tanpa adanya paksaan dari luar (Wasti, 2013). Sedangkan jika menurut Slameto minat merupakan rasa kecenderungan terhadap sesuatu dalam hal memperhatikan dan mengenang beberapa aktivitas (Siagian, 2015). Sehingga dapat disimpulkan bahwa minat merupakan rasa atau perasaan yang timbul dalam diri siswa yakni perasaan senang dan memiliki kecenderungan untuk memperhatikan sehingga memberikan dampak yang positif kepada siswa.

Menurut Slameto 2003 (Pangestu et al., 2015) minat dalam belajar merupakan bentuk dari suatu keaktifan seseorang untuk mendorong nya melakukan serangkaian aktivias guna membantu untuk mendapatkan perubahan dalam tingkah laku dari hasil pengalaman nya dengan lingkungan yang mencakup perubahan pada aspek kognitif, afektif dan psikomotor.

Pentingnya minat dalam belajar untuk dimiliki oleh siswa ini salah satu nya adalah karena minat memiliki pengaruh yang besar terhadap hasil belajar siswa. Selain itu, minat erat kaitan nya dengan belajar, tanpa adanya minat proses pembelajaran akan terasa kosong atau dengan kata lain yakni membosankan. Siswa yang memiliki minat akan sangat antusias dan bersemangat ketika belajar dibandingan dengan siswa yang kurang memiliki minat. Minat siswa terhadap suatu materi atau mata pelajaran akan sangat memungkinkan besarnya keberhasilan atau hasil dari proses belajar tersebut (Gusniwati, 2015).

Minat dalam belajar juga tentunya tidak tumbuh begitu saja, banyak sekali faktor yang dapat mempengaruhi minat belajar siswa khususnya dalam belajar matematika. Selain peran guru, faktor lain yang dapat mempengaruhi minat belajar adalah bahan ajar itu sendiri atau materi pelajarannya. Terkadang, materi yang cukup sulit untuk dipelajari membuat siswa merasa malas untuk mengerjakan nya atau siswa cenderung mudah menyerah. Contoh nya pada materi sistem persamaan linear 
tiga variabel (SPLTV) yang dipelajari di kelas X di semester satu. Seperti yang diketahui bahwa materi SPLTV ini memiliki penyelesaian yang cukup rumit. Tetapi, jika dilihat berdasarkan fungsi dan tujuan nya materi SPLTV ini sangat penting serta dapat membantu masyarakat khususnya siswa dalam menyelesaikan permasalahan kontekstual. Hal ini lah yang membuat guru atau para pendidik sebagai fasilitator di dalam proses pembelajaran perlu menumbuhkan minat siswa dalam belajar matematika khususnya pada materi SPLTV.

Menurut Sudaryono (2012) untuk mengukur besarnya minat belajar yang dimiliki siswa dapat melalui : 1) Rasa Kesukaan, 2) Rasa Ketertarikan, 3) Perhatian, dan 4) Keterlibatan Siswa (Simbolon, 2014). Indikator-indikator tersebut dapat dilihat secara langsung ketika proses belajar. Siswa yang memiliki minat cenderung aktif dikelas, karena pada dasarnya indikator tersebut dapat mendorong siswa untuk aktif dalam hal positif di kelas. Sebaliknya, jika siswa yang kurang memiliki minat akan cenderung pasif. Siswa akan merasa sibuk dengan dunianya sendiri, tidak menghiraukan guru, malas memperhatikan dan hal lainnya sehingga nantinya akan memberikan hasil belajar yang kurang baik.

Berdasarkan dari latar belakang diatas, bahwa minat merupakan salah satu komponen penting yang harus dimiliki oleh siswa ketika mengikuti proses pembelajaran, terlebih ketika di masa pandemi seperti ini. Seperti yang diketahui bahwa proses pembelajaran secara daring ini tentunya tidak mudah bagi guru dan juga siswa, minat siswa dalam proses pembelajaran secara daring ini sangat dibutuhkan khususnya pada mata pelajaran matematika. Sebab dengan adanya minat, siswa akan senantiasa belajar dengan senang hati dan menimbulkan rasa sungguh-sungguh dalam belajar, bertanya kepada guru jika ada materi yang kurang dipahami ataupun dalam mengerjakan tugas-tugas yang diberikan sehingga siswa akan memiliki rasa kepuasan setelah menerima pembelajaran.

\section{Metode Penelitian}

Penelitian ini menggunakan pendekatan kualitatif. Menurut Meleong (2017) penelitian kualitatif merupakan penelitian yang bermaksud untuk mengetahui serta memahami lebih dalam terkait dengan kejadian/fenomena yang dialami oleh subjek penelitian. Jenis penelitian ini adalah penelitian kualitatif deskriptif, yang mana dalam didalam penelitian ini peneliti ingin mendeskripsikan terkait minat belajar matematika siswa SMA kelas X. Menurut Meleong (2017) metode deskriptif merupakan cara pengumpulan data yang berupa penjelasan melalui kata-kata, melalui gambar dan bukan merupakan angka-angka (Parulian, Munandar, \& Ruli, 2019).

Instrumen yang digunakan yakni angket/kuesioner yang berjumlah 18 butir item pernyataan yang didalam nya memuat pernyataan positif dan pernyataan negatif serta hasil observasi selama pembelajaran matematika berlangsung. Penggunaan angket pada penelitian kali ini adalah hasil modifikasi dari Munawwaroh (2020) yang memuat 4 indikator dalam mengukur minat belajar matematika siswa, diantaranya : 1) Perasaan Senang/Suka, 2) Perhatian, 3) Ketertarikan, dan 4) Keterlibatan Siswa.

Kriteria penskoran dari penelitian ini menggunakan skala Likert. Pengukuran pada tipe skala ini terdiri dari 4 (empat) tipe jawaban, yakni : 1) Selalu, 2) Sering, 3) Jarang, dan 4) Tidak Pernah. Atau dapat dilihat pada tabel di bawah ini:

Tabel 1. Kriteria Penskoran Angket Minat Belajar

\begin{tabular}{ccccc}
\hline $\begin{array}{c}\text { Alternatif } \\
\text { Jawaban }\end{array}$ & Selalu & Sering & Jarang & Tidak Pernah \\
\hline Item (+) & 4 & 3 & 2 & 1 \\
Item (-) & 1 & 2 & 3 & 4 \\
\hline
\end{tabular}



Selain itu, untuk kriteria minat belajar dalam penelitian ini adalah menurut Suyitno 2004 (Akbar, Nuriman, \& Agustiningsih, 2014) seperti tabel berikut :

Tabel 2. Kategorisasi Minat Belajar

\begin{tabular}{cc}
\hline Kriteria Minat & Kategori \\
\hline $80 \%<\mathrm{KM}<100 \%$ & Sangat Tinggi \\
$60 \%<\mathrm{KM}<80 \%$ & Tinggi \\
$40 \%<\mathrm{KM}<60 \%$ & Cukup \\
$20 \%<\mathrm{KM}<40 \%$ & Kurang \\
$\mathrm{KM} \leq 20 \%$ & Sangat Kurang \\
\hline
\end{tabular}

Suyitno, 2004 (Akbar et al., 2014).

\section{Hasil dan Pembahasan}

Penelitian ini dilakukan di salah satu SMA Negeri di Karawang. Subjek yang dipilih dalam penelitian ini adalah siswa/siswi SMA Kelas X yang terdiri dari dua kelas yakni satu kelas untuk jurusan MIPA dan satu kelas lagi untuk jurusan IPS. Pengumpulan data dilakukan melalui pengisian angket minat belajar serta hasil observasi kepada siswa selama proses pembelajaran matematika berlangsung khususnya pada materi SPLTV.

Dari hasil analisis pengisian angket diperoleh hasil masing-masing persentase dari tiap-tiap indikator sebagai berikut :

\begin{tabular}{|c|c|c|c|}
\hline No. & Indikator & Persentase & Kategori \\
\hline 1 & $\begin{array}{l}\text { Perasaan } \\
\text { Senang }\end{array}$ & $55,88 \%$ & Cukup \\
\hline 2 & Perhatian & $50,74 \%$ & Cukup \\
\hline 3 & $\begin{array}{l}\text { Rasa } \\
\text { Ketertarikan }\end{array}$ & $58,53 \%$ & Cukup \\
\hline 4 & $\begin{array}{l}\text { Keterlibatan } \\
\text { Siswa }\end{array}$ & $53,68 \%$ & Cukup \\
\hline
\end{tabular}

Berdasarkan Tabel 3 di atas diketahui bahwa persentase indikator paling besar ada pada indikator ketiga atau memiliki rasa ketertarikan. Sedangkan untuk indikator paling rendah atau kecil ada pada indikator kedua atau memiliki perhatian. Meskipun demikian, masingmasing dari indikator tersebut masih berada di kategori yang sama yakni pada kategori cukup.

\section{a) Indikator Pertama (Memiliki Perasaan Senang)}

Perasaan senang merupakan suatu perasaan yang jika dimiliki oleh individu ketika melakukan suatu kegiatan maka akan memberikan dorongan untuk terus menindak lanjuti. Demikian pula dengan siswa, siswa yang memiliki perasaan senang ketika belajar akan senantiasa belajar tanpa adanya suatu paksaan.

Dari hasil analisis angket minat belajar pada indikator pertama atau memiliki perasaan senang diperoleh : pada kategori tinggi sebanyak 4 orang, kategori cukup sebanyak 12 orang dan kategori kurang 1 orang. Dengan hasil persentase pada indikator pertama sebesar 55,88\% sesuai dengan tabel 3 diatas.

Sedangkan dalam keseharian nya yang diketahui dari hasil pengamatan perasaan senang yang dimiliki siswa selam proses pembelajaran matematika terbilang kurang. Hal ini didasari oleh selama proses pembelajaran hanya sedikit siswa yang mengikuti proses belajar tersebut meskipun diantara siswa tersebut sudah mengetahui jadwal belajar. Kemudian, hanya sebagian kecil dikelas yang merespon guru ketika guru memberikan bahan ajar yang telah disiapkan oleh guru agar siswa dapat mempelajari materi dengan semaksimal mungkin. Hal ini lah yang menunjukkan bahwa kurang nya rasa senang dalam diri siswa ketika proses pembelajaran matematika.

\section{b) Indikator Kedua (Memiliki Perhatian) \\ Memiliki perhatian ketika proses} pembelajaran merupakan hal yang penting. Sebab, siswa yang memiliki perhatian akan cenderung memperhatikan apa yang disampaikan oleh guru ketika proses pembelajaran berlangsung dan akan berdampak pada pemahaman siswa sehingga akan memberikan hasil yang positif terhadap hasil belajarnya.

Dari hasil analisis angket minat belajar pada indikator kedua, diperoleh : Pada kategori tinggi sebanyak 1 orang, kategori cukup sebanyak 6 orang, kategori kurang sebanyak 9 orang dan pada kategori sangat kurang sebanyak 1 orang. Dari data 
tersebut rata-rata persentase yang diperoleh dari indikator kedua atau memiliki perhatian ini sebanyak 50,74\%.

Sedangkan dar hasil data observasi, rasa perhatian siswa ketika proses pembelajaran matematika terbilang kurang. Hal ini dikarenakan hampir sebagian besar dari siswa masih kurang memperhatikan guru ketika proses pembelajaran, siswa tidak mempelajari bahan ajar yang diberikan oleh guru dan siswa cenderung mengabaikan pembelajaran matematika.

\section{c) Indikator Ketiga (Memiliki Rasa Ketertarikan)}

Rasa tertarik pada suatu mata pelajaran akan membuat seseorang terus berusaha dalam mencapai apa yang dia inginkan. Siswa akan dengan giat mempelajari serta mencari tahu terkait apa yang menjadi daya tariknya, sehingga proses pembelajaran menjadi lebih bermakna.

Hasil analisi angket minat belajar pada indikator ketiga diperoleh : pada kategori tinggi sebanyak orang, kategori cukup sebanyak 9 orang dan kategori kurang sebanyak 2 orang. Dari hasil tersebut persentase pada indikator memiliki ketertarikan sebanyak 58,53 \% seperti yang telah disebutkan pada Tabel 3 di atas.

Tidak banyak dari siswa yang memiliki rasa tertarik terhadap pembelajaran matematika khusus nya pada materi SPLTV dengan alasan bahwa materi SPLTV ini merupakan materi yang sulit serta pengerjaan nya yang cukup panjang membuat siswa kurang merasakan ketertarikan terhadap materi ini serta tidak jarang siswa yang tidak mengumpulkan tugas atau pun siswa yang telat dalam pengumpulan yang tidak sesuai dengan jadwal yang telah ditentukan.

\section{d) Indikator Keempat (Keterlibatan Siswa)}

Siswa dianggap terlibat ketika proses pembelajaran jika siswa tersebut ikut andil dalam proses pembelajaran tersebut. Siswa yang ikut terlibat dalam proses pembelajaran biasanya akan terbilang cukup aktif, sebab siswa akan melakukan diskusi baik itu dengan teman sebayanya maupun dengan guru nya, serta mengerjakan dan mengumpulkan latihanlatihan soal yang telah diberikan.

Hasil analisis angket minat belajar siswa pada indikator keempat diperoleh hasil : pada kategori sangat tinggi sebanyak 1 orang, kategori tinggi sebanyak 7 orang, kategori cukup sebanyak 3 orang dan kategori kurang sebanyak 6 orang. Dan hasil persentase dari indikator keterlibatan siswa sebanyak $53,68 \%$.

Dari hasil pengamatan, diketahui bahwa masih kurang nya keterlibatan siswa terhadap proses pembelajaran matematika. Hal ini ditandai dengan ketika guru memberikan kesempatan untuk bertanya terkait apa yang belum mereka pahami dari materi yang sedang dipelajari siswa cenderung diam, hanya sebagain kecil dari siswa yang merespon dan bertanya. Ketika guru bertanya terkait materi sedikit pula yang mampu menjawab pertanyaan serta hanya sebagian siswa yang mengumpulkan tugas dan latihan soal. Pengumpulan tugas ini dapat dikatakan sebagai bentuk usaha siswa agar ikut terlibat dalam proses pembelajaran.

Hasil dari angket minat belajar siswa dengan hasil observasi memiliki kontradiksi yang cukup kuat. Setelah dicek kembali, banyak siswa yang menyatakan pernyataan yang tidak sesuai dengan apa yang mereka alami. Oleh sebab itu, data angket yang diperoleh tidak sepenuh nya menggambarkan minat belajar matematika siswa. Sehingga, data hasil observasi mengenai minat belajar siswalah yang menjadi argumen kuat untuk menyatakan bagaimana minat siswa dalam proses pembelajaran matematika.

Selain itu, jika dilihat dari hasil belajar nya, hasil yang diperoleh oleh siswa masih dibawa rata-rata. Sebagain siswa masih belum mengerti terkait dengan cara menyelesaikan permasalahan SPLTV. Siswa masih merasa bingung membedakan cara dari masing-masing metode penyelesaian SPLTV dan banyak dari siswa yang keliru terkait dengan langkah-langkah yang seharusnya digunakan untuk menyelesaikan suatu permasalahan.

Karena pada dasarnya hasil belajar juga tidak luput dari pengaruh minat, maka 
siswa yang memiliki hasil belajar yang kurang baik dapat dikatakan kurang memiliki minat dalam belajar. Hal ini juga berdasarkan Wasliman (Fadillah, 2016) yang menyatakan bahwa hasil belajar siswa salah satunya dipengaruhi oleh minat yang dimiliki oleh siswa.

Proses pembelajaran daring memang terbilang kurang efektif. Proses pembelajaran non-tatap muka yang terkadang membuat siswa malas untuk belajar. Rasa malas sendiri salah satu nya ditimbulkan karena kurang nya minat siswa dalam belajar. Hal ini tentunya menjadikan minat sebagai salah satu komponen yang wajib untuk diperhatikan lebih khusus agar pembelajaran dapat berjalan dengan lancar dan sesuai tujuan pembelajaran yang telah ditentukan.

Terlebih lagi dalam pembelajaran matematika khusus nya pada materi SPLTV memang memiliki cara pengerjaan yang cukup panjang dan harus memiliki ketelitian dan ketekunan agar mendapatkan hasil seperti yang diinginkan. Oleh karena itu, peran guru sangat dibutuhkan dalam meningkatkan minat belajar siswa khususnya pada saat proses pembelajaran matematika.

\section{Simpulan}

Meskipun dari hasil angket minat belajar siswa semua indikator memiliki persentase yang mengkategorikan indikator-indikator tersebut pada kategori cukup. Tetapi secara umum serta berdasarkan hasil dari pengataman atau observasi yang dilakukan oleh peneliti selama proses pembelajaran berlangsung peneliti menyimpulkan bahwa minat dalam belajar siswa SMA ini masih termasuk ke dalam kategori kurang. Hal ini dikarenakan masih banyaknya indikator-indikator dari minat belajar yang belum terpenuhi dari diri siswa. Oleh sebab itu, peranan guru sangat dibutuhkan agar dapat meningkatkan minat siswa dalam belajar terlebih lagi di masa pandemi seperti ini. Salah satu nya adalah pemilihan media pembelajaran yang tepat untuk situasi serta materi pelajaran dan strategi pembelajaran lainnya yang diharapkan mampu dalam meningkatkan minat belajar siswa. Sehingga siswa tidak merasa jenuh/bosan selama proses pembelajaran karena mencoba hal yang baru.

\section{Daftar Pustaka}

Akbar, R. M., Nuriman, \& Agustiningsih. (2014). Peningkatan Minat dan Hasil Belajar IPA Pokok Bahasan Energi Panas dan Bunyi Melalui Penerapan Metode Eksperimen pada Siswa Kelas IV B MI Muhammadiyah Sidorejo Tahun Pelajaran 2013 /2014. 13, 15.

Fadillah, A. (2016). Analisis Minat Belajar dan Bakat Terhadap Hasil Belajar Matematika Siswa. M A T H L INE : Jurnal Matematika dan Pendidikan Matematika, 1(2), 113-122. https://doi.org/10.31943/mathline.v1i2 .23

Gusniwati, M. (2015). Pengaruh Kecerdasan Emosional dan Minat Belajar terhadap Penguasaan Konsep Matematika Siswa SMAN di Kecamatan Kebon Jeruk. Formatif: Jurnal Ilmiah Pendidikan MIPA, 5(1), 26-41. https://doi.org/10.30998/formatif.v5i1. 165

Marti'in. (2019). Analisis tentang rendahnya minat belajar peserta didik kelas XI SMA Negeri 5 Pontianak.

Pangestu, A. D., Samparadja, H., \& Tiya, K. (2015). Pengaruh minat terhadap hasil belajar matematika siswa SMA Negeri 1 Uluiwoi kabupaten Kolaka Timur. Jurnal Penelitian Pendidikan Matematika, 3(2), 17-26.

Parulian, R. A., Munandar, D. R., \& Ruli, R. M. (2019). Analisis Kemampuan Pemecahan Masalah Matematis dalam Menyelesaikan Materi Bilangan Bulat pada Siswa SMP. Prosiding Seminar Nasional Matematika dan Pendidikan Matematika Sesiomadika 2019, 345354. Retrieved from http://journal.unsika.ac.id/index.php/s esiomadika 
Rahmah, N. (2013). Hakikat Pendidikan Matematika. Al-Khwarizmi: Jurnal Pendidikan Matematika Dan Ilmu Pengetahuan Alam, 2, 1-10. https://doi.org/10.24256/jpmipa.v1i2.8 8

Siagian, R. E. F. (2015). Pengaruh Minat dan Kebiasaan Belajar Siswa terhadap Prestasi Belajar Matematika.

Formatif: Jurnal Ilmiah Pendidikan MIPA, 2(2), 122-131. https://doi.org/10.30998/formatif.v2i2. 93

Simbolon, N. (2014). Faktor Faktor Yang Mempengaruhi Minat Belajar Peserta Didik. Elementary School Journal Pgsd Fip Unimed, 1(2), 14-19.

Wasti, S. (2013). Hubungan minat belajar dengan hasil belajar mata pelajaran tata busana di Madrasah Aliyah Negeri 2 Padang. 